\title{
An unusual case of ectopic abdominal pregnancy in a bitch - a case report
}

\author{
Alan Maksimović1 *, Dajna Preldžić², Ismar Lutvikadićc , Amir Zahirović², \\ Dženita Hadžijunuzović-Alagićc ${ }^{3}$, and Denis Čamo ${ }^{2}$ \\ ${ }^{1}$ Department of Veterinary Surgery, Veterinary Faculty, University of Sarajevo, Sarajevo, Bosnia and Herzegovina \\ ${ }^{2}$ Department of Internal Diseases of Domestic Animals, Veterinary Faculty, University of Sarajevo, Sarajevo, \\ Bosnia and Herzegovina \\ ${ }^{3}$ Department of Veterinary Radiology and Physical Therapy, Veterinary Faculty, University of Sarajevo, Sarajevo, \\ Bosnia and Herzegovina
}

MAKSIMOVIĆ, A., D. PRELDŽIĆ, I. LUTVIKADIĆ, A. ZAHIROVIĆ, DŽ. HADŽIJUNUZOVIĆALAGIĆ, D. ČAMO: An unusual case of ectopic abdominal pregnancy in a bitch - a case report. Vet. arhiv 90, 535-541, 2020.

\section{ABSTRACT}

There are only a few reported cases of abdominal ectopic pregnancy and consequential foetal mummification in dogs. The majority of the described cases indicate that this condition may exist for a prolonged period of time without any manifestation of illness. Therefore, sudden signs of abdominal distension, abdominal pain, episodes of epileptiform seizures, dark diarrhoea and lethargy, as were observed in the present case, are not likely to be considered as symptoms of an abdominal ectopic pregnancy. Furthermore, to the best of our knowledge, this is the first report of an eight-year long abdominal pregnancy in an ovariohysterectomised bitch. We present the clinical, laboratory, radiological and intraoperative findings, and the medical and surgical therapy for an abdominal ectopic pregnancy in a 14 year old Miniature Pinscher bitch, ovariohysterectomised eight years previously.

Key words: dog; foetal mummification; previously ovariohysterectomised

\section{Introduction}

Ectopic pregnancy (EP), or extrauterine pregnancy, is a condition characterized by the implantation and subsequent development of a fertilized egg (ovum) outside the uterus. In relation to the location of extrauterine embryo development, ectopic pregnancies are referred to as tubal or abdominal pregnancy. Tubal pregnancy is defined as embryo development in the fallopian tubes. It is very rare in non-primate animals, and it is not recognized as a clinical entity in dogs (CORPA, 2006; EDDEY, 2012). Abdominal pregnancy

is characterized by the gestation process taking place inside the peritoneal cavity (CORPA, 2006). According to the stage of foetal development, the discontinuation of the pregnancy is defined by two separate terms. The first is defined as embryonic death which occurs in early pregnancy and results in the rapid autolysis of tissue with resorption through the endometrium. The second is foetal death, and it may happen prior to, or after, completion of the foetal ossification process (LEFEBVRE, 2015). Foetal mummification is a sterile process which

\footnotetext{
*Corresponding author:

Assist. Prof. Alan Maksimović, DVM, MSc, PhD, Department of Veterinary Surgery, University of Sarajevo Veterinary faculty, Zmaja od Bosne 90, 71000 Sarajevo, Bosnia and Herzegovina, Phone: +387 33729 100; Fax: +387 33 617 850; E-mail: alan.maksimovic@vfs.unsa.ba
} 
occurs in a case of foetal death only if the process of foetal bone development is complete (BINDARI and SHRESTHA, 2012). It can be divided into two types: papyraceous and hematic mummification. Papyraceous mummification results in a dry and stiff foetus, with no fluids between or in the tissue, while hematic mummification produces a viscous material which covers the foetus (LEFEBVRE, 2015).

Currently, there are few reports of ectopic abdominal pregnancy in dogs (SCHLOTTHAUER and WAKIM, 1955; PECK and BADAME, 1966; EDDEY, 2012; MYUNG et al., 2016), all of which were much shorter in duration and in intact bitches. The present paper describes a case of abdominal EP with foetal mummification in a Miniature Pinscher bitch, ovariohysterectomised eight years previously.

\section{Materials and methods}

A fourteen-year-old, female spayed Miniature Pinscher presented with episodes of mild epileptiform seizures, dark diarrhoea and lethargy. The anamnesis and physical examination of the patient were followed by blood sampling from the cephalic vein into a sterile IDEXX $\mathrm{K}_{2}$ EDTA VetCollect ${ }^{\circledR}$ tube and a L-heparin LH/1.3 microtube (SARSTEDT AG \& Co. KG) for haematology and biochemistry blood tests. Haematological blood analysis was performed using a LaserCyte ${ }^{\circledR}$ Hematology Analyzer, (Idexx Laboratories Inc.), and blood biochemistry using a Catalyst One ${ }^{\circledR}$ Chemistry Analyzer, (Idexx Laboratories Inc). Right and left lateral, and ventrodorsal view abdominal radiographs were obtained, and urgent surgery was performed due to the diagnosed ectopic pregnancy. Induction of general anaesthesia for surgery was accomplished with a $5 \mathrm{mg} / \mathrm{kg}$ intravenous bolus mixture of ketamine hydrochloride (Ketaminol ${ }^{\circledR}$ 10, Intervet Internation B.V., Netherland) and 0.25 $\mathrm{mg} / \mathrm{kg}$ diazepam (Apaurin ${ }^{\circledR}$, Krka d.d, Slovenia). The trachea was intubated and epidural anaesthesia performed using the technique described by VALVERDE (2008), administering $4 \mathrm{mg} / \mathrm{kg}$ of lidocaine (lidokain hidrohlorid 2\%, Galenika a.d., Serbia) in combination with $1.0 \mathrm{mg} / \mathrm{kg}$ of tramadol (TramadolSTADA $100 \mathrm{mg} / 2 \mathrm{~mL}$, STADA -Arzneimittel AG, Germany). Intraoperative general anaesthesia was maintained with isoflurane in oxygen. The state of anaesthesia was evaluated by assessment of the muscular tonus of the jaw, pupil dilatation, eyeball position, response to surgery, and monitored physiological parameters. Physiological parameters (heart rate, respiratory rate, arterial haemoglobin oxygen saturation and non-invasive oscillometric arterial blood pressure) were monitored by a machine (PM-9000Vet, Mindray, China) supervised by an anaesthesiologist. The surgical field was routinely prepared and sterile draped. Explorative laparotomy was performed through an abdominal ventral midline incision from the xiphoid process of the sternum to the pubis. Removal of the mummified abdominal foetus required resection of the adhered jejunum. Jejunal resection and anastomosis were performed according to TOBIAS (2010). The intestines were atraumatically clamped with Doyen forceps, several centimetres beyond the proposed transection sites, and the mesenteric blood vessels of the segment to be resected were double ligated and terminal arcuate single ligated. Transection was performed at a slight angle to the long axis of the intestine, and the diameter of the intestinal ends was adjusted by antimesenteric surface incisions. Mesenteric and antimesenteric sutures were placed to ensure the proper alignment of the anastomotic edges. Sutured intestinal anastomosis was performed using a singlelayer closure over a simple continuous pattern (3-0 polydioxanone, Kruuse, Denmark), with submucosa included. The quality of the anastomotic seal was tested by injecting sterile saline into the portion of the intestinal lumen atraumatically clamped by the assistant's fingers. The anastomosis was omentalized with the free edge of the omentum, tacked with simple interrupted sutures (4-0 Polyglycolide-poly Copolymer, Kruuse, Denmark), and the abdomen was routinely closed in three layers. During the perioperative period, due to suspicion of systemic inflammatory response syndrome, the dog was given supportive therapy, including isotonic intravenous fluids in a dose of $40 \mathrm{~mL} / \mathrm{kg}$ (0,9\% Natrii Chloride infundibile, Hemofarm a.d., Serbia), with a combination of broad-spectrum antibiotics: $15 \mathrm{mg} / \mathrm{kg}$ of cephtriaxone q $12 \mathrm{~h}\left(\right.$ Triax $^{\circledR}$, Bosnalijek d.d, Bosnia and Herzegovina), $15 \mathrm{mg} / \mathrm{kg}$ of metronidazole (Efloran ${ }^{\circledR}$, Krka d.d., Slovenia) q 12 hours. Analgesia was managed with $0.2 \mathrm{mg} / \mathrm{kg}$ of meloxicam $\left(\right.$ Melox $^{\circledR}$, NOBEL İLAÇ SAN. VE TİC. A.Ş., Turkey) q 24 hours. 


\section{Results}

The anamnesis highlighted gravidity, approximately eight years previously, resulting in dystocia. A Caesarean section was performed to deliver one dead puppy, followed by ovariohysterectomy. The recovery period was marked by septicaemia, treated by broad spectrum antibiotics. After the recovery, the dog did not have any further serious health issues.

On the day of presentation, the patient was bright, alert and responsive. Its body condition score was 5/9 (WSAVA, 2013). General clinical examination revealed ischemic mucous membranes, capillary refill time less than 2 seconds, and that the peripheral lymph nodes were not enlarged. Heart and respiratory rates were within reference ranges. Thoracic auscultation revealed no abnormalities. The abdomen was distended and very painful on palpation. A firm mass was palpated, the size of a tangerine, in the right mesogastric region.

The blood analysis showed regenerative, normochromic and normocytic anaemia, neutrophilia, monocytosis, basophilia and thrombocytosis. Biochemistry analysis revealed hyperglycaemia, hyperglobulinemia and elevated alkaline phosphatase, as well as hypochloraemia.

The radiographs demonstrated a radiopaque mass (foetal skeleton) in the ventral right mesogastric region (Fig. 1, Fig. 2).

Exploration of the abdomen revealed a midabdominal mass, the size of a large tangerine, adhered to and enclosed in the omentum, multiple parts of the jejunum and mesentery (Fig. 3). The ovaries and uterus were not found. Step by step, blunt and electrocauterisation dissection of the adhesions between the organ tissues and the mass allowed separation of the mummified foetus (Fig. 4). Several parts of the jejunum were discovered with visible communication developed between the lumen and the mass (in the form of ruptures). Resection was performed including all the damaged parts, and followed by termino-terminal anastomosis assessed by the syringe test. The abdominal incision was closed in routine fashion.

Unexpectedly, the patient died during the night, at home, two days after surgery. The owners declined the suggested necropsy.

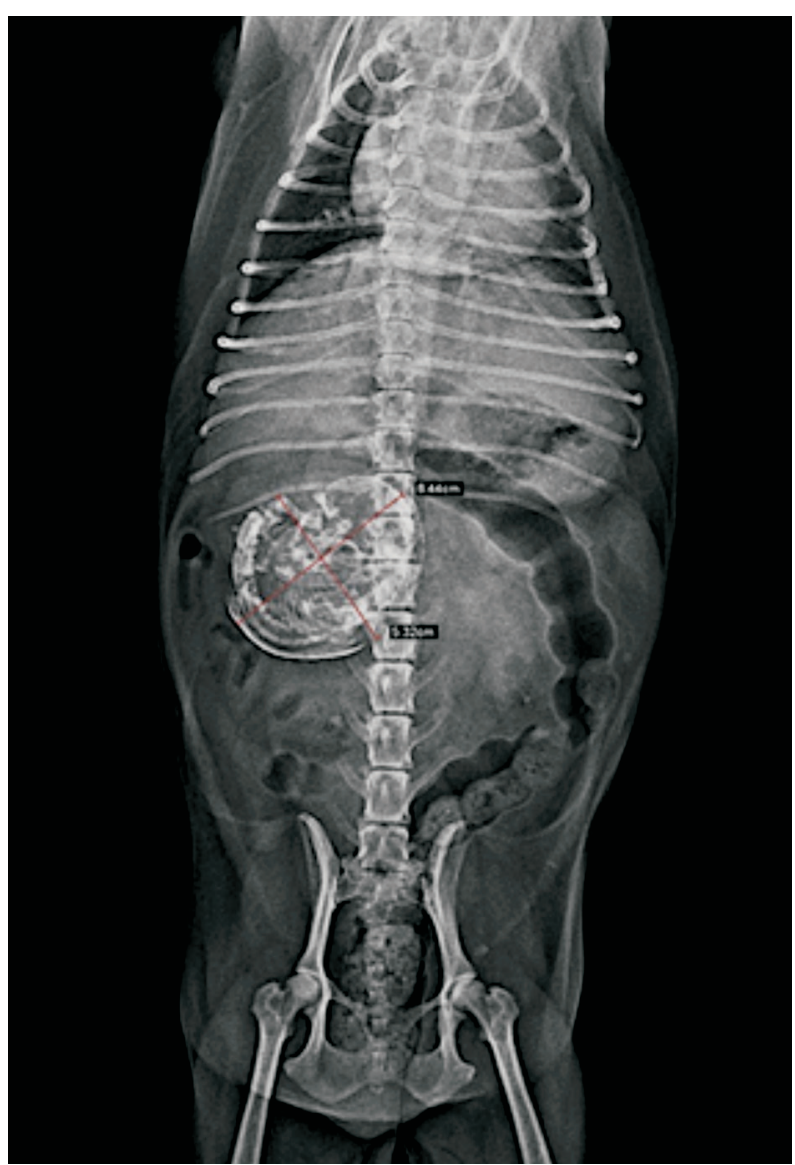

Fig. 1. Ventrodorsal view demonstrating intraabdominal foetal skeleton

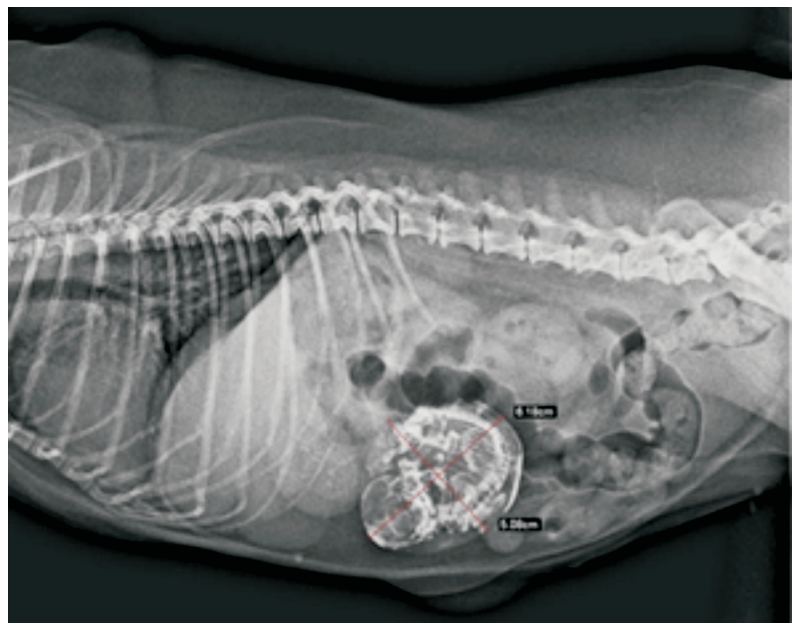

Fig. 2. Right lateral view demonstrating intraabdominal foetal skeleton 


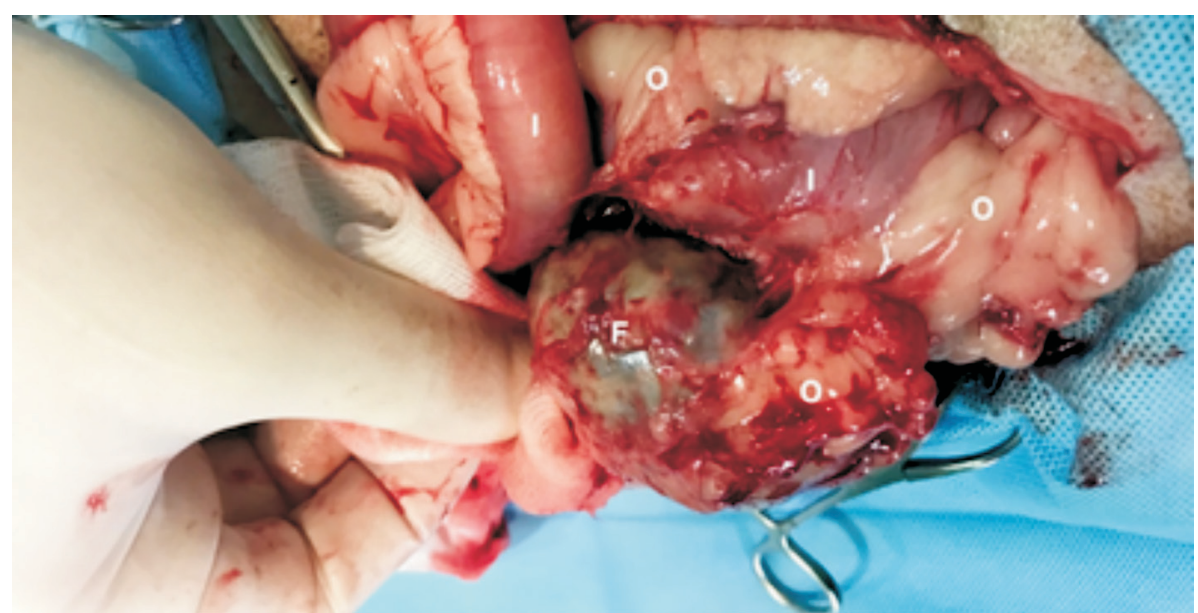

Fig. 3. Intraoperative photography of the abdominal foetus (F) with adhered intestines (I) and omentum (O)

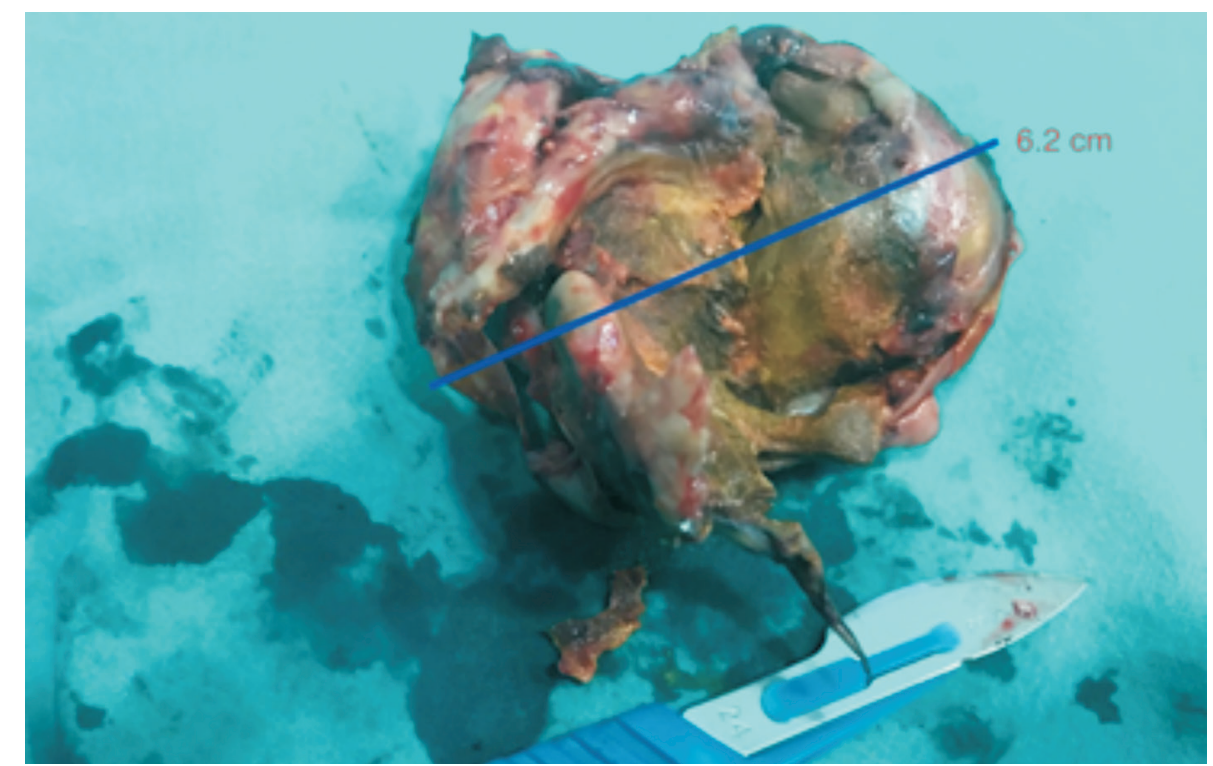

Fig. 4. Photography of mummified foetus after removal from the abdomen

\section{Discussion}

Ectopic pregnancy when there is an abnormally located embryo or foetus, outside of the uterus. In an abdominal EP, the conceptus is located within the abdominal cavity, while a tubular EP represents implantation within the oviduct. Abdominal EP is further classified as primary or secondary, based on the location of the initial implantation (CORPA, 2006; EDDEY, 2012). Generally, EP is considered rare in animals, although detailed epidemiological studies have not been conducted (CORPA, 2006; MYUNG et al., 2016). Tubal pregnancies have not been reported in domestic animals (EDDYE, 2012). In dogs, all cases of EP, with consequential fetal mummification, have been abdominal (SCHLOTTHAUER and WAKIM, 1955; KUHLMAN and KOVAN, 1956; PECK and BADAME, 1966; EDDEY, 2012; MYUNG et al., 2016). The majority of these cases are classified as secondary abdominal EP due to a uterine rupture. If uterine rupture does not occur, the foetus may be found mummified within the uterus (EFENDIĆ et al., 2018). True primary EP can only occur 
in primates, including humans, rodents, and lagomorphs, because of the discoid villous placenta (CORPA, 2006; OSENKO and TERELLO, 2014). In the present case, the uterus was removed eight years earlier by ovariohysterectomy, so we could not examine it and confirm whether there was a uterine rupture or not. The observed characteristics of the ectopic foetus (Fig. 4) corresponded to papyraceous mummification. The foetus appeared dark brown, leathery and without odour. In such cases, autolysis of tissues stops, dehydration starts to develop, and bacterial colonization is inhibited. The process of desiccation leads to shrinkage of the skin, other tissues and bones, developing a dense connection between the foetus and placenta (LEFEBVRE, 2015). We can speculate, considering the anamnesis of dystocia resolved by urgent caesarean section, followed by ovariohysterectomy, that the diagnosed foetal mummification was the result of secondary abdominal EP due to the spontaneous rupture of the uterus. Also, considering that the foetus appeared grossly to be close to term, the proposed spontaneous rupture probably occurred at the time of parturition. The foetus's move from the uterus into the abdomen during the caesarean section is unlikely, although given this possibility, we cannot exclude. Caesarean section as a risk factor for abdominal pregnancy, as suggested by SCHLABRITZ-LOUTSEVITCH et al. (2004) in the case of EP in a baboon. Also, abdominal EP has been described in spayed cats, several months after ovariohysterectomy (CARRIG et al., 1972; KNOTT, 1989; NACK, 2000). In these cases, primary abdominal EP was proposed. In the present case, it is not clear how it could be possible that the extrauterine localization of the foetus was not seen during the caesarean section and ovariohysterectomy. To the best of our knowledge, all previously published cases in dogs were described in intact females. The present case reports ectopic abdominal pregnancy and consequential foetal mummification in a previously ovariohysterectomised bitch. It is also interesting that the assumed minimal duration of the ectopic abdominal pregnancy in our case was much longer (eight years) than all previous reports in this animal species. The longest previously reported duration of an EP in a dog was five months (EDDEY, 2012).
OSENKO and TARELLO (2014) described a 7 -year-old EP pregnancy in a spayed cat. The only symptoms were poor appetite, increased thirst and urination. No clear association has yet been defined between the duration of the ectopic pregnancy and the development of clinical signs (NACK, 2000). As in our case, previous reports proved that an abdominal ectopic pregnancy may exist for a prolonged period of time without any manifest evidence of illness (EDDEY, 2012; MYUNG et al., 2016). If presented, clinical signs are mild and unspecific (decreased appetite, retching, and/ or vomiting) (CORPA, 2006). Sudden signs of abdominal distension, abdominal pain, episodes of epileptiform seizures, dark diarrhoea and lethargy are unlikely to be considered as symptoms of an abdominal ectopic pregnancy, as was observed in the present case. Considering the intraoperative findings, these symptoms are the result of the secondary partial adherent intestinal obstruction and the communication developed between the intestinal lumen and the mass. Small bowel obstruction developed secondary to a ruptured tubal pregnancy was previously reported in humans (SINGH et al., 2009).

Adhesions from an inflammatory process that developed on the conjunction site between the mummified foetus and other organs, mostly intestines, may be considered as a cause of secondary intestinal incarceration, resulting in small intestinal obstruction (WILLARD, 2014). This condition presents the potential risk of developing rupture of the intestines, with consequential bacterial colonization and translocation outside of the gastrointestinal tract and the release of endotoxins, which leads to the development of systemic inflammatory response syndrome (SIRS). SIRS is a clinical condition characterized by activation of the body's inflammatory system, and may be caused by septic agents or have non-septic causes (DE LAFORCADE, 2008). Due to the large portion of compromised jejunum in this patient, we consider that the secondary intestinal obstruction caused systemic inflammatory response syndrome. Diagnosis of SIRS was made on the basis of the proposed criteria extrapolated from human medicine, also used in animals, and symptoms 
which developed prior to hospitalization. The intermittent dark stool observed could be explained by bleeding in the proximal intestines where the mummified foetus was positioned. The effects of SIRS and intestinal bleeding were noticed in the complete blood count as regenerative, normocytic and normochromic anaemia, neutrophilia, basophilia and monocytosis. Plasma chemistry changes presenting hyperglycaemia also supported the diagnosis of SIRS. Therefore, increased gluconeogenesis and possible hypoinsulinemia, represent higher risk for infection and morbidity, as they have a further direct inhibitory effect on the immune system (HAUPTMAN et al., 1997; DE LAFORCADE, 2008).

The elevation of the alkaline phosphatase values may be explained by the intestinal inflammation and obstruction. It may also be explained by leakage of the intestinal and liver enzymes, as the foetus adhered to the gastrointestinal tract and entered the intestinal lumen. Hypochloraemia is a common finding in intestinal obstruction, due to fluid loss from diarrhoea and/or vomiting, which can lead to metabolic alkalosis (WILLARD, 2014). Animals with SIRS have concurrent organ injury. Besides inflammatory leucogram, other signs and clinical findings that develop as a consequence of inflammatory mediators are vasodilation, increased capillary permeability, and mitochondrial dysfunction, which leads to tissue ischaemia. Tissue ischaemia is mostly caused by hypoxaemia, oxidative stress and circulatory collapse. This could explain the epileptiform seizures, which are probably a consequence of the inflammatory effect of cytokines on the nervous system as one of the organ systems, besides gastrointestinal tract, that is at risk for dysfunction secondary to SIRS.

\section{Conclusions}

In conclusion, the absence of related clinical signs for a period of eight years proves that an abdominal ectopic pregnancy may exist for a very long period of time without any evidence of illness manifested. The observed sudden signs of illness reflect a complication of the abdominal EP with the development of secondary pathological processes and consequential systemic inflammatory response syndrome.

\section{References}

BINDARI, Y. R., S. SHRESTHA (2012): Canine fetal mummification. Inter. J. Vet. Sci. 1, 10-12.

CARRIG, C. B., I. M. GOURLEY, A. L. PHILBRICK (1972): Primary abdominal pregnancy in a cat subsequent to ovariohysterectomy. J. Am. Vet. Med. Assoc. 160, 308-310.

CORPA, J. M. (2006): Ectopic pregnancy in animals and humans. Reproduction 131, 631-640.

DOI: $10.1530 /$ rep. 1.00606

DE LAFORCADE, A. M. (2008): Systemic inflammatory response syndrome. In: Small Animal Emergency and critical care medicine (Silverstein, D., K. Hopper, Eds.), Saunders Elsevier, pp. 30-34.

EDDEY, P. D. (2012): Ectopic Pregnancy in an apparently healthy bitch. J. Am. Anim. Hosp. Assoc. 48, 194-197.

EFENDIĆ, M., M. SAMARDŽIJA, H. CAPAK, G. BAČIĆ, N. MAĆEŠIĆ (2018): Hormonal induction of abortion of mummified fetus in a breeding weimaraner bitch. Slo. Vet. Res. 55, 193-200

DOI: $10.5326 /$ JAAHA-MS-5732E

HAUPTMAN, J. G., R. WALSHAW, N. B. OLIVIER (1997): Evaluation of the sensitivity and specificity of diagnostic criteria for sepsis in dogs. Vet. Surg. 26, 393-397.

DOI: 10.1111/j.1532-950X.1997.tb01699.x

KNOTT, C. D. (1989): Ectopic pregnancy in a cat. Vet. Rec. $124,666$.

DOI: $10.1136 / v r .124 .25 .666-\mathrm{a}$

KUHLMAN, W. H., D. J. KOVAN (1956): Postparturient, extrauterine canine fetus. J. Am. Vet. Med. Assoc. 128, 131.

LEFEBVRE, R. C. (2015): Fetal mummification in the major domestic species: current perspectives on causes and management. Veterinary Medicine: Research and Reports 6, 233-244.

DOI: 10.2147/VMRR.S59520

MYUNG, H. W., A. J. LEE, J. Y. KIM, J. H. KIM, K. D. EOM, H. J. KIM, S. H. DO, H. Y. KIM, D. J. CHUNG (2016): Secondary abdominal pregnancy with foetal mummification diagnosed using computed tomography in a dog: a case report. Vet. Med -Czech. 61, 51-55.

DOI: 10.17221/8682-VETMED

NACK, R. A. (2000): Theriogenology question of the month. An ectopic fetus. J. Am. Vet. Med. Assoc. 217, 182-184.

DOI: $10.2460 /$ javma.2000.217.182

OSENKO, A., W. TERELLO (2014): A 7-year-old extrauterine pregnancy in a cat. Case Reports in Veterinary Medicine. Volume 2014, 1-3, Article ID 145064.

DOI: $10.1155 / 2014 / 145064$

PECK, G. K., F. G. BADAME (1966): Extra-uterine pregnancy with fetal mummification and pyometra in a Pomeranian. Can. Vet. J. 8, 136-127.

SCHLABRITZ-LOUTSEVITCH, N. E., G. B. HUBBARD, P. A. FROST, L. B. CUMMINS, E. J. DICK, P. W. JR 
NATHANIELSZ, T. J. MCDONALD (2004) Abdominal pregnancy in a baboon: a first case report. J. Med. Primatol. $33,55-59$.

DOI: $10.1046 / j .1600-0684.2003 .00044 . x$

SCHLOTTHAUER, C. F., K. G. WAKIM (1955): Ectopic pregnancy in a dog. J. Am. Vet. Med. Assoc. 127, 213.

SINGH, S., B. K. JAIN, D. MOHANTY, J. AGRAWAL, S. MEHTA (2009): Ruptured ectopic pregnancy presenting as intestinal obstruction. Can. J. Surg. 52, E99-E100.

TOBIAS, K. M. (2010): Intestinal resection and anastomosis. In: Manual of Small Animal Soft Tissue Surgery. (Tobias, K. M., Ed.), Wiley-Blackwell, Iowa, pp. 175-182.
VALVERDE, A. (2008): Epidural analgesia and anesthesia in dogs and cats. Vet. Clin. North Am. Small. Anim. Pract. 38, 1205-1230.

DOI: $10.1016 /$ j.cvsm.2008.06.004

WILLARD, M. D. (2014): Disorders of intestinal tract: Intestinal obstruction. In: Small Animal Internal Medicine $5^{\text {th }}$ ed. (Nelson,C. G., R. W. Couto, Eds.), Saunders Elsevier, pp. 477-478.

WSAVA Global Nutrition Committee (2013): Body Condition Score. https://www.wsava.org/WSAVA/media/Arpita-andEmma-editorial/Body-Condition-Score-Dog.pdf

MAKSIMOVIĆ, A., D. PRELDŽIĆ, I. LUTVIKADIĆ, A. ZAHIROVIĆ, DŽ. HADŽIJUNUZOVIĆALAGIĆ, D. ČAMO: Neuobičajen slučaj abdominalne ektopijske gravidnosti kuje - prikaz slučaja. Vet. arhiv 90, 535-541, 2020.

\section{SAŽETAK}

Dosad je opisano svega nekoliko slučajeva ektopijske gravidnosti pasa, s posljedičnom mumifikacijom ploda. Većina njih pokazuje da ovo stanje može biti prisutno dulje vrijeme bez kliničkih simptoma. Stoga se iznenadna pojava znakova bolesti kao što su bolnost i nadutost abdomena, epileptiformni napadaji, tamna stolica i letargija, ustanovljeni u našem slučaju, ne bi smatrali simptomima koji bi u diferencijalnu dijagnozu uvrstili ektopijsku gravidnost. Također, ovo je prvi prikaz slučaja ektopijske gravidnosti ovariohisterektomizirane kuje u trajanju od osam godina. Prikazani su opaženi simptomi, laboratorijski i rendgenski nalazi, intraoperacijsko stanje, kao i poduzeta medikamentna i kirurška terapija kuje minijaturnog pinčera, u dobi od 14 godina, koja je podvrgnuta ovariohisterektomiji osam godina prije.

Ključne riječi: pas; fetalna mumifikacija; prethodna ovariohisterektomija 
